\title{
PENGARUH KEPEMILIKAN SAHAM PEMERINTAH DAN KEPEMILIKAN SAHAM ASING TERHADAP PENGUNGKAPAN TANGGUNG JAWAB SOSIAL PERUSAHAAN DENGAN UKURAN PERUSAHAAN DAN PROFITABILITAS SEBAGAI VARIABEL KONTROL \\ (Studi Empiris pada Perusahaan yang Terdaftar di Bursa Efek Indonesia)
}

\author{
Oleh : \\ Wa Asrida \\ (Dosen Jurusan Akuntansi Politeknik Negeri Ambon)
}

\begin{abstract}
This study aims to obtain empirical evidence regarding: (1) the influences of government ownership and foreign ownership is simultaneously toward corporate social responsibility disclosure on companies listed in Indonesia Stock Exchange; (2) the influences of government ownership and foreign ownership is partial toward corporate social responsibility disclosure on companies listed in Indonesia Stock Exchange.The population of this study are all companies listed in Indonesia Stock Exchange (IDX) in 2010. Sampling study using purposive sampling method. The total study sample was 64 companies. Data analysis was performed with a classical test assumptions and hypothesis testing with multiple linier regression method. The result of the research gives an empiric evidence tells that: (1) government ownership and foreign ownership is simultaneously has a significant influences toward corporate social responsibility disclosures on companies listed in Indonesia Stock Exchange (IDX); (2) government ownership have no significant influence toward corporate social responsibility disclosure on companies listed in Indonesia Stock Exchange (IDX); (3) foreign ownership have no significant influence toward corporate social responsibility disclosure on companies listed in Indonesia Stock Exchange (IDX).
\end{abstract}

Key words: government ownership, foreign ownership, corporate social responsibility disclosure.

\section{Latar Belakang}

Dewasa ini tuntutan terhadap perusahaan semakin besar, perusahaan diharapkan tidak hanya mementingkan kepentingan manajemen dan pemilik modal (investor dan kreditor) tetapi juga karyawan, konsumen serta masyarakat. Akan tetapi perusahaan kadangkala melalaikannya dengan alasan bahwa mereka tidak memberikan kontribusi terhadap kelangsungan hidup perusahaan. Hal ini disebabkan hubungan perusahaan dengan lingkungannya bersifat non reciprocal yaitu tidak menimbulkan prestasi timbal balik. Tuntutan terhadap perusahaan untuk memberikan informasi yang transparan, organisasi yang akuntabel serta tata kelola perusahaan yang semakin bagus, semakin memaksa perusahaan untuk memberikan informasi mengenai aktivitas sosialnya. Masyarakat membutuhkan informasi mengenai sejauh mana perusahaan sudah melaksanakan aktivitas sosialnya sehingga hak masyarakat untuk hidup aman dan tentram, kesejahteraan karyawan, dan keamanan mengkonsumsi makanan dapat terpenuhi. Oleh karena itu dalam perkembangan sekarang ini akuntansi konvensional telah banyak dikritik karena tidak dapat mengakomodir kepentinganmasyarakat secara luas, sehingga kemudian muncul konsep akuntansi baru yang disebut sebagai Social Responsibility Accounting (SRA) atau Akuntansi Sosial.

Salah satu informasi yang sering diminta untuk diungkapkan perusahaan saat ini adalah informasi tentang tanggung jawab sosial perusahaan. Tanggung jawab sosial perusahaan itu sendiri dapat digambarkan sebagai ketersediaan informasi keuangan dan non-keuangan berkaitan dengan interaksi organisasi dengan lingkungan fisik dan lingkungan sosialnya, yang dapat dibuat dalam laporan tahunan perusahaan atau laporan sosial terpisah (Guthrie dan Mathews, 1989) dalam Puspitasari (2009). CSR sebagai sebuah gagasan menjadikan perusahaan tidak lagi dihadapkan pada tanggung jawab yang berpijak pada single bottom line, yaitu nilai perusahaan (corporate value) yang direfleksikan dalam kondisi keuangannya (financial) saja. Tapi tanggung jawab perusahaan harus berpijak pada triple bottom lines yaitu juga memperhatikan masalah 
sosial dan lingkungan (Wibisono, 2007). Karena kondisi keuangan saja tidak cukup menjamin nilai perusahaan tumbuh secara berkelanjutan (sustainable).

Pengungkapan kinerja lingkungan, sosial, dan ekonomi di dalam laporan tahunan atau laporan terpisah adalah untuk mencerminkan tingkat akuntabilitas, responsibilitas, dan transparansi perusahaan kepada investor dan stakeholders lainnya. Pengungkapan tersebut bertujuan untuk menjalin hubungan komunikasi yang baik dan efektif antara perusahaan dengan publik dan stakeholders lainnya tentang bagaimana perusahaan telah mengintegrasikancorporate social responsibilty (CSR) dalam setiap aspek kegiatan operasinya (Darwin, 2004 dalam Angraini, 2006). Selain itu, perusahaan juga dapat memperoleh legitimasi dengan memperlihatkan tanggung jawab sosial melalui pengungkapan CSR dalam media termasuk dalam laporan tahunan perusahaan (Haniffa et al, ${ }^{\dagger} 2005$ ). Hal yang sama juga dikemukan oleh Kiroyan (2006), dalam Sayekti dan Wondabio (2007) menyatakan bahwa dengan menerapkan CSR, diharapkan perusahaan akan memperoleh legitimasi sosial dan memaksimalkan kekuatan keuangannya dalam jangka panjang. Hal ini mengindikasikan bahwa perusahaan yang menerapkan CSR mengharapkan akan direspon positif oleh para pelaku pasar.

Fenomena yang terkait dengan tanggung jawab sosial perusahaan adalah persoalan sosial dan lingkungan hidup yang ditimbulkan oleh aktivitas perusahaan, baik perusahaan nasional maupun perusahaan asing di Indonesia yang banyak mendapat protes dari kalangan LSM. Misalnya kasus sumburan gas PT. Lapindo Brantas di Sidoarjo Jawa Timur, kasus PT.Newmont Minahasa Raya di Buyat Sulawesi dan kasus yang paling dominan dan telah mengakar cukup lama adalah konflik antara masyarakat adat Papua (khususnya suku Amungme dan Komoro) dengan PT Freeport Indonesia yang juga melibatkan pemerintah. Konflik ini merupakan fenomena gunung es (iceberg phenomenon) karena apa yang terlihat dan teramati publik, hanyalah konflik-konflik di permukaan. Sementara, hakikat konflik yang bersifat laten dan lebih besar, tidak mudah dideteksi.

Selain masalah sosial, PT. Freeport juga menimbulkan berbagai persoalan ekologi. Limbah yang dihasilkan oleh PT Freeport (tailing) mencemari tiga badan sungai utama di wilayah Mimika, Sungai Aghawagon, Sungai Otomona dan Sungai Ajkwa. Dalam tabel 1.1 di bawah ini, dijelaskan secara sistematis bagairnana PT. Freeport Indonesia menimbulkan dampak kerusakan terhadap lingkungan yang cenderung masih primer di Kawasan Timur Indonesia (Aditjondro, www.parasindonesia.com, 05 mei 2011).

Kasus yang sama terjadi pada PT. Indorayon Utama (sekarang PT. Toba Pulp Lestari) di Porsea Sumatra Utara. Pada tahun 1998 perusahaan ditutup akibat reaksi dari masyarakat karena tidak adanya tanggung jawab sosial perusahaan, sehingga tidak saja menimbulkan kerugian materi tetapi sampai masalah keberlangsungan usaha. Pada tahun 2003, perusahaan beroperasi kembali dengan etika dan budaya perusahaan yang baru yaitu mengutamakan masalah sosial dan kemanusiaan. Dengan adanya berbagai contoh kasus tersebut menuntut perusahaan untuk melaksanakan tanggung jawab sosial perusahaan.

Menurut Tanudjaja (2009) perbedaan dalam memaknai CSR oleh perusahaan akan menyebabkan perbedaan implementasi CSR antar perusahaan pula, tergantung bagaimana perusahaan tersebut memaknai CSR. Di sini letak pentingnya pengaturan CSR, agar memiliki daya atur, daya ikat dan daya dorong. Dengan demikian regulasi pemerintah terhadap pelaporan CSR dapat berperan penting untuk mendorong perusahaan menghasilkan laporan CSR. Perihal penerapan CSR di Indonesia telah diatur dalam beberapa peraturan perundang-undangan dan keputusan menteri, yaitu UU RI No. 23 tahun 1997 tentang pengelolaan lingkungan hidup, UU RI No. 19 tahun 2003 tentang BUMN pasal 2 ayat (1) huruf e "salah satu maksud dan tujuan pendirian BUMN adalah turut aktif memberikan bimbingan dan bantuan kepada pengusaha golongan ekonomi lemah, koperasi dan masyarakat", pasal 88 ayat (1) BUMN dapat menyisihkan sebagian laba bersihnya untuk keperluan pembinaan usaha kecil/koperasi serta pembinaan masyarakat sekitar BUMN. Sebagai tindak lanjut dari pasal 2 dan 88 UU BUMN No. 19/2003, diterbitkan Keputusan Menteri BUMN Nomor: Kep-236/MBU/2003 tentang Program Kemitraan Badan Usaha Milik Negara dengan Usaha Kecil dan Program Bina Lingkungan (PKBL), keputusan tersebut disempurnakan dengan Keputusan Menneg BUMN No. Per-05/MBU/2007.

Peraturan lain yang menyentuh CSR adalah Keputusan ketua BAPEPAM No. 134/BL/2006 tentang kewajiban penyampaian laporan tahunan bagi emiten atau perusahaan publik. UU RI No. 25 tahun 2007 tentang Penanaman Modal, pasal 15 (b) menyatakan bahwa 
"setiap penanaman modal berkewajiban melaksanakan tanggung jawab sosial perusahaan", pasal 17 menyatakan bahwa "penanaman modal yang mengusahakan sumber daya alam yang tidak terbarukan wajib mengalokasikan dana secara bertahap untuk pemulihan lokasi yang memenuhi standar kelayakan lingkungan hidup, yang pelaksanaannya diatur sesuai dengan ketentuan peraturan perundang-undangan" dan pasal 34 tentang "sanksi administratif", meskipun UU ini telah mengatur saanksi-sanksi secara terperinci terhadap badan usaha atau usaha perseroan yang mengabaikan CSR, UU ini baru mampu menjangkau investor asing dan belum mengatur secara tegas perihal CSR bagi perusahaan nasional.

UU No. 40 tahun 2007 tentang Perseroan Terbatas pasal 74 ayat (1) yang menyebutkan bahwa "perseroan yang menjalankan usahanya dibidang atau berkaitan dengan sumber daya alam wajib melaksanakan tanggung jawab sosial dan lingkungannya". ayat (2) "tanggung jawab sosial perusahaan merupakan kewajiban perseroan yang dianggarkan dan diperhitungkan sebagai biaya perseroan yang pelaksanaanya dilakukan dengan memperhatikan kepatuhan dan kewajaran" dan ayat (3) "perseroan yang tidakmelaksanakan kewajiban dikenai sanksi sesuai ketentuan dan perundangundangan. Selanjutnya Bab IV pasal 66 ayat $2 \mathrm{~b}$ menyatakan bahwa laporan tahunan perusahaan harus mencerminkan tanggung jawab sosial perusahaan. UU No.40 Tahun 2007 tentang Perseroan Terbatas yang mewajibkan CSR merupakan salah satu upaya pemerintah untuk menyeimbangkan pertumbuhan ekonomi dan pemerataan ekonomi. Dengan demikian CSR(corporate social responsibility) atau tanggung jawab sosial perusahaan yang sebelumnya merupakan suatu hal yang bersifat sukarela akan berubah menjadi suatu hal yang wajib dilaksanakan.

Standar Akuntansi Keuangan yang dikeluarkan oleh Ikatan Akuntan Indonesia pun telah mengakomodasi tentang akuntansi pertanggungjawaban sosial, yaitu PSAK No. 1 paragrafke-12 : "Entitas dapat pula menyajikan, terpisah dari laporan keuangan, laporan mengenai lingkungan hidup dan laporan nilai tambah (value added statement), khususnya bagi industri dimana faktor lingkungan hidup memegang peranan penting dan bagi industri yang menganggap karyawan sebagai kelompok pengguna laporan yang memegang peranan penting. Laporan tambahantersebut di luar ruang lingkup Standar Akuntansi Keuangan". Pernyataan IAI dalam PSAK tersebut merupakan manifestasi kepedulian akuntansiakan masalah-masalah sosial yang merupakan wujud pertanggungjawaban sosial perusahaan.

Hadi dan Sabeni (2002) dalam Rawi (2008) menyatakan bahwa salah satu faktor yang mempengaruhi luas pengungkapan dalam laporan tahunan suatu perusahaan adalah basis perusahaan tersebut. Basis perusahaan dapat dilihat dari kepemilikan sahamnya, apakahperusahaan tersebut mayoritas sahamnya dimiliki pemerintah atau dimiliki swasta/asing. Kepemilikan saham oleh pemerintah menyebabkan perusahaan tersebut dalam menjalankan aktivitasnya harus selaras dengan kepentingan pemerintah. Pemerintah berhak menunjuk direktur perusahaan tersebut sehingga keputusan bisnis yang diambil merupakan kepanjangan tangan dari kepentingan pemerintah (Amran dan Devi, 2008). Untuk dapat bertahan, perusahaan ini harusdapat mensinkronkan dirinya dengan pemerintah. Di Indonesia perusahaan ini disebut dengan Badan Usaha Milik Negara (BUMN). Mayoritas sahamnya dimiliki oleh pemerintah, sehinggastakeholder utama perusahaan ini adalah pemerintah. Penelitian Amran dan Devi (2008)menemukan bahwa kepemilikan saham oleh pemerintah memilki pengaruh yang signifikan terhadap pelaporan CSR di Malaysia. Sedangkan penelitian yang dilakukan oleh Izah dan Ibrahim (2008) menemukan hubungan yang negatif dan signifikan antara kepemilikan saham pemerintah dengan pengungkapan sosial perusahaan di Jordania.

Demikian halnya dengan kepemilikan saham asing, dimana negara-negara asing terutama Eropa dan United State merupakan negara-negara yang sangat memperhatikan isu-isu sosial dan lingkungan seperti pelanggaran hak asasi manusia, pendidikan, tenaga kerja, dan isu lingkunganseperti, efek rumah kaca, pembalakan liar, serta pencemaran air. Negara-negara asing cenderung lebih perhatian terhadap aktivitas serta pengungkapan CSR. Pengungkapan tanggung jawab sosial merupakan salah satu media yang dipilih untuk memperlihatkan kepedulian perusahaan terhadap masyarakat di sekitarnya. Dengan kata lain, apabila perusahaan di Indonesia memiliki kontrak dengan foreign stakeholders baik dalam ownership dan trade, maka perusahaan akanlebih didukung dalam melakukan pengungkapan tanggung jawab sosial perusahaan. Penelitian yang dilakukan oleh Mackmud dan Djakman (2008); Amran dan Devi (2008) menemukan bahwa kepemilikan asing tidak memiliki pengaruh yang signifikan terhadap pengungkapan tanggung jawab 
sosial perusahaan. Penelitian Carmelo (2009) menemukan bahwa terdapat hubungan yang signifikan antara kepemilikan asing dengan pengungkapan sosial perusahaan.

Kondisi perusahaan juga mempengaruhi kinerja serta luas pengungkapan dalam laporan tahunan perusahaan. Kondisi perusahaan dapat dilihat dari ukuran perusahaan danprofitabilitas perusahaan (Puspitasari, 2009). Pada penelitian ini ukuran perusahaan (firm size) dan profitabilitas merupakan variabel kontrol. Variabel kontrol digunakan untuk menetralisir pengaruh variabel-variabel luar yang tidak perlu, dan atau menjembatani hubungan antara variabelindependen dengan variabel dependen. Selain itu tujuan digunakan variabel kontrol adalah untuk mengeleminir kemungkinan kesalahan dalam pengambilan kesimpulan.

Secara umum perusahaan yang besar mengungkapkan lebih banyak informasi dibandingkan perusahaan yang lebih kecil. Dalam teori keagenan diungkapkan bahwa perusahaan besar memiliki biaya keagenan yang lebih besar daripada perusahaan kecil, sehingga perusahaan besar cenderung akan mengungkapkan informasi yang lebih banyak sebagai upaya untuk mengurangi biaya keagenan tersebut (Jansen \& Meckeling, 1976 ; Gray et. al., 2001). Akan tetapi, tidak semua penelitian mendukung hubungan antara size perusahaan dengan tanggung jawab sosial perusahaan. Penelitian yang tidak berhasil menunjukkan hubungan kedua variabel ini adalah penelitian yang dilakukan oleh Davey (1982); Ng (1985) dan Robert (1992) dalam Hackston dan Milne (1996). Penelitian yang berhasil menunjukkan hubungan kedua variabel ini antara lain Chow et al,. (1987); Belkaoui dan Karpik (1989); Hackston dan Milne (1996); Sembiring (2005); Izah dan Ismail (2009); dan Carmelo (2009).

Profitabilitas merupakan suatu kemampuan perusahaan untuk menghasilkan laba dan untuk meningkatkan nilai pemegang saham. Menurut Heinze (1976); Gray, et al. (1995); dalam Sembiring (2005) profitabilitas merupakan faktor yang membuat manajemen menjadi bebas dan fleksibel untuk mengungkapkan CSR kepada pemegang saham. Oleh karena itu, semakin tinggitingkat profitabilitas perusahaan maka semakin besar pengungkapan informasi sosialnya. Penelitian Hackston dan Milne (1996); Sembiring (2005); Anggraini (2006); dan Carmelo(2009) tidak berhasil menemukan hubungan antara profitabilitas dengan pengungkapan tanggung jawab sosial perusahaan.

Penelitian ini dilakukan karena isu mengenai CSR kini mendapat tempat di seluruh dunia, dan memperoleh pengakuan dari kalangan dunia usaha, pemerintah, dan LSM. Bahkan CSR dianggap sebagai bagian atau parameter dari praktik bisnis yang sangat ideal. Berdasarkan beberapa penelitian yang pernah dilakukan sebelumnya membuktikan bahwa pengaruh kepemilikan saham pemerintah dan kepemilikan saham asing, serta variabel kontrol ukuran perusahaan dan profitabilitas terhadap pengungkapan tanggung jawab sosial perusahaan menunjukkan hasil yang tidak konsisten.

Penelitian ini merupakan replikasi terutama dari penelitian Carmelo (2009) yang menguji variabel kepemilikan saham asing, ukuran perusahaan dan profitabilitas. Pada penelitian ini penulis menambahkan satu variabel baru yaitu kepemilikan saham pemerintah. Perbedaan penelitian ini dengan penelitian sebelumnya adalah objek penelitian ini dilakukan pada perusahaan yang terdaftar di Bursa Efek Indonesia, sedangkan penelitian sebelumnya dilakukan di Bursa Efek Spanyol. Dalam penelitian ini ukuran perusahaan dan profitabilitas digunakan sebagai variabel kontrol, sedangkan penelitian sebelumnya ukuran perusahaan dan profitabilitas digunakan sebagai variabel penjelas. Sampel akhir penelitian ini 64 perusahaan, sedangkan sampel penelitian terdahulu 46 perusahaan. Adanya perbedaan tersebut memungkinkan hasil penelitian yang berbeda pula.

\section{Rumusan Masalah}

Berdasarkan latar belakang penelitian yang telah diuraikan sebelumnya, permasalahan yang diajukan dalam penelitian ini adalah sebagai berikut :

1. Apakah kepemilikan saham pemerintah (government ownership) dan kepemilikan saham asing (foreign ownership) secara simultan berpengaruh signifikan terhadap luas pengungkapan tanggung jawab sosial perusahaan yang terdaftar di Bursa Efek Indonesia.

2. Apakah kepemilikan saham pemerintah (government ownership) dan kepemilikan saham asing (foreign ownership) secara parsial berpengaruh positif signifikan terhadap luas pengungkapan tanggung jawab sosial perusahaan yang terdaftar di Bursa Efek Indonesia. 


\section{Kerangka Pemikiran}

Dalam penelitian ini karekteristik perusahaan yang mempengaruhi pengungkapan CSR dalam laporan tahunan saham pemerintah (government ownership) dankepemilikan saham asing (foreign ownership), dengan ukuran perusahaan (firm size) danprofitabilitas (profitability) sebagai variabel kontrol.

Kepemilikan saham oleh pemerintah menyebabkan perusahaan tersebut dalam menjalankan aktivitasnya harus selaras dengan kepentingan pemerintah. Perusahaan yang memiliki struktur kepemilikan pemerintah akan lebih sensitif secara politik karena kegiatan-kegiatan perusahaan akan lebih diperhatikan oleh publik. Hal ini dikarenakan perusahaan yang memiliki struktur kepemilikan pemerintah maka secara tidak langsung perusahaan tersebut dimilikioleh masyarakat luas. Dengan demikian, perusahaan dapat terlibat lebih dalam kegiatan sosial, sehingga masyarakat luas akan melegitimasi keberadaan perusahaan tersebut. Hal ini sesuai dengan teori legitimasi yang menyatakan bahwa perusahaan dapat bertahan apabila masyarakat sekitarnya merasa bahwa perusahaan telah melakukan kegiatan operasinya sesuai dengan nilai-nilai yang dimiliki oleh masyarakat (Gray et. al., 1995). Diharapkan perusahaan di mana pemerintah sebagai pemegang saham mayoritas akan mengungkapan informasi yang lebih mengenai pengungkapan tanggung jawab sosial dalam laporan tahunan.

Tekanan pemerintah dan publik yang kuat membuat perusahaan ini harus lebih transparan dalam pengelolaannya. Perusahaan menggunakan laporan tahunan sebagai salah satu media pelaporan pertanggungjawaban manajemen mereka sebagaimana diatur dalam UU PT No. 40 Tahun 2007. Pengungkapan yang lebih besar merupakan wujud akuntabilitas atas pengelolaan perusahaan.

Adanya peraturan yang mewajibkan perusahaan melaksanakan CSR membuat perusahaan dengan kepemilikan saham pemerintah lebih tanggap terhadap peraturan yang ada, karena pemerintah mempunyai power untuk menekan perusahaan melaksanakan CSR. Semakin besar kepemilikan saham pemerintah, perusahaan semakin konsen untuk melaksanakan CSR dan akan berdampak pada semakin luas pengungkapan tanggung jawab sosial perusahaan. Perusahaan menggunakan laporan tahunan sebagai salah satu media pelaporan pertanggungjawaban manajemen atas pelaksanaan CSR. Pengungkapan yang lebih luas merupakan wujud akuntabilitas atas" pengelolaan perusahaan. Dengan demikian perusahaan ini diharapkan menjadi panutan bagi perusahaan-perusahaan yang lain.

Penelitian Amran dan Devi (2008) menemukan hubungan yang signifikan antara kepemilikan saham pemerintah dengan pengungkapan CSR. Hal ini sesuai dengan pendapatSteiner and Steiner (5:2003) yang mengatakan bahwa, "Pemerintah adalah pihak yang mempunyai wewenang untuk membuat dan melaksanakan kebijakan dan peraturan, kekuatan dan peraturan pemerintah ini akan berpengaruh terhadap perusahaan". Izah dan Ibrahim (2008) dalam penelitiannya menemukan hubungan yang negatif dan signifikan antara kepemilikan saham pemerintah dengan pengungkapan CSR di Jordania, kepemilikan pemerintah tinggi cenderung mengungkapkan CSR kurang dari perusahaan dengan kepemilikan pemerintah rendah.

Penerapan CSR di Indonesia dapat diindikasikan sebagai akibat peningkatan nilai perusahaan asing setelah menerapkan CSR di dalam operasional perusahaan. Nilai-nilai tersebut diterapkan oleh perusahaan yang dibentuk oleh para investor asing dalam kegiatan operasional perusahaan di Indonesia. Perusahaan berbasis asing memiliki teknologi yang cukup, skilkkaryawan yang baik, jaringan informasi yang luas, sehingga memungkinkan melakukan disclosuresecara luas. Seperti diketahui, negara-negara luar terutama Eropa dan United State merupakan negaranegara yang sangat memperhatikan isu-isu sosial; seperti pelanggaran hak asasi manusia, pendidikan, tenaga kerja, dan isu lingkungan seperti, efek rumah kaca, pembalakan liar, serta pencemaran air. Negara-negara asing cenderung lebih perhatian terhadap aktivitas serta pengungkapan CSR. Pengungkapan tanggung jawab sosial merupakan salah satu media yang dipilih untuk memperlihatkan kepedulian perusahaan terhadap masyarakat di sekitarnya. Dengan kata lain, apabila perusahaan di Indonesia memiliki kontrak denganforeign stakeholders baik dalam ownership dan trade, maka perusahaan akan lebih didukung dalam melakukan pengungkapan tanggung jawab sosial.

Di Indonesia, banyak penelitian yang menggunakan foreign ownership sebagai variabel independen yang mempengaruhi pengungkapan CSR dalam laporan tahunan perusahaan. Hal ini 
disebabkan karena kepemilikan saham asing baik perorangan maupun perusahaan hanya taat pada peraturan dan konsen pada isu-isu sosial dan lingkungan di negaranya, tapi tidak berlaku di Indonesia. Adanya berbagai kasus seperti PT. Newmont dan PT. Freeport membuktikan ketidak pedulian investor asing terhadap isu-isu sosial dan lingkungan di Indonesia. Berlawanan dengan hasil penelitian di atas, Carmelo (2009) menemukan bahwa terdapat hubungan yang signifikan antara kepemilikan asing dengan pengungkapan sosial perusahaan, hasil tersebut membuktikan adanya kepedulian investor asing terhadap isu-isu sosial dan lingkungan pada negara tempat mereka berinvestasi.

Ukuran perusahaan sebagai variabel kontrol dalam penelitian ini merupakan salah satu faktor yang mempengaruhi pengungkapan informasi sosial. Ukuran perusahaan menunjukkan besar kecilnya kekayaan yang dimiliki oleh perusahaan. Umumnya perusahaan-perusahaan besar akan mengungkapkan informasi lebih banyak dari pada perusahaan kecil karena perusahaan besar memiliki biaya keagenan yang lebih besar dari pada perusahaan kecil (Sembiring, 2005). Oleh sebab itu untuk mengurangi biaya keagenan tersebut perusahaan besar cenderung akan mengungkapkan informasi yang lebih banyak. Selanjutnya Robert dan Gray (1995) dalam Sembiring (2005) mengungkapkan bahwa perusahaan besar mempunyai kemampuan untuk merekrut karyawan yang ahli, serta adanya tuntutan dari pemegang saham dan analis, sehingga perusahaan besar memiliki insentif untuk melakukan pengungkapan yang lebih luas dari pada perusahaan kecil. Perusahaan besar merupakan entitas yang paling banyak disoroti oleh pasar maupun publik secara umum. Sehingga mengungkapkan lebih banyak informasi merupakan bagian dari upaya perusahaan untuk mewujudkan akuntabilitas publik. Penelitian yang berhasil menunjukkan hubungan kedua variabel ini antara lain Hackston dan Milne (1996); Sembiring (2005); Izah dan Ismail (2009); dan Carmelo (2009).

Profitabilitas merupakan faktor yang membuat manajemen menjadi bebas dan fleksibel untuk mengungkapkan pertanggungjawaban sosial kepada pemegang saham (Heinze (1976) dalam Hackston dan Milne (1996). Ketika perusahaan memiliki tingkat laba yang tinggi, perusahaan (manajemen) menganggap tidak perlu melaporkan hal-hal yang dapat mengganggu informasi tentang sukses keuangan tersebut. Sebaliknya ketika tingkat profitabilitas rendah perusahaan akan berharap pengguna laporan akan membaca good news kinerja perusahaan. Sementara itu, penelitian yang dilakukan Bowman dan Haire (1976) dalam Hackston dan Milne (1996) menunjukkan bahwa semakin tinggi tingkat profitabilitas perusahaan maka semakin besar pengungkapan informasi sosial.

Berdasarkan rumusan masalah dan kerangka pemikiran yang telah diuraikan sebelumnya, maka rancangan hipotesis pada penelitian ini adalah:

Hipotesis 1 :Kepemilikan saham pemerintah (government ownership) dan kepemilikan saham asing (foreign ownership) secara simultan berpengaruh signifikan terhadap pengungkapan tanggung jawab sosial perusahaan yang terdaftar di Bursa Efek Indonesia.

Hipotesis 2: Kepemilikan saham pemerintah (government ownership)berpengaruh positif terhadap pengungkapan tanggung jawab sosial perusahaan yang terdaftar di Bursa Efek Indonesia.

Hipotesis 3 :Kepemilikan saham asing (foreign ownership) berpengaruh positif terhadap pengungkapan tanggung jawab sosial perusahaan yang terdaftar di Bursa Efek Indonesia.

\section{Metodologi Penelitian}

Objek yang akan diteliti dalam penelitian ini adalah kepemilikan saham pemerintah(government ownership), kepemilikan saham asing (foreign ownership), ukuran perusahaan (firm size), profitabilitas (profitability) dan pengungkapan tanggung jawab sosial perusahaan. Unit analisis dalam penelitian ini adalah perusahaan terbuka yang terdaftar (listing) di Bursa Efek Indonesia tahun 2010. Data yang digunakan dalam penelitian ini adalah data sekunder yang diperoleh dengan cara pengumpulan dan dokumentasi di Bursa Efek Indonesia. Pendokumentasian bersumber dari laporan tahunan (annual report) tahun 2010 dari 64 perusahaan sampel.

\section{Operasionalisasi Variabel}

Berdasarkan kerangka pemikiran yang telah dipaparkan sebelumnya, variabel dalam penelitian ini terdiri dari independen variable (variabel bebas), variabel kontrol dan dependen variable (variabel terikat) yang dapat dijabarkan sebagai berikut: 


\section{Variabel Independen}

Yang menjadi variabel independen dalam penelitian ini adalah kepemilikan saham pemerintah (government ownership) dan kepemilikan saham asing (foreign ownership) yang dapat diketahui melalui analisis terhadap laporan tahunan pada 64 perusahaan sampel yang terdaftar di Bursa Efek Indonesia tahun 2010.

\section{a. Kepemilikan Saham Pemerintah (Government Ownership) (X1)}

Kepemilikan saham pemerintah dalam penelitian ini menggunakan persentase pemilikan saham Pemerintah Indonesia. Kepemilikan tersebut minimal sebesar 5\% yang dilihat dalam laporan tahunan perusahaan tahun 2010. Besarnya saham pemerintah diukur dengan rasio dari jumlah kepemilikan saham pemerintah dibagi dengan total saham perusahaan. Metode pengukuran diatas berdasarkan pengukuran yang telah dilakukan oleh Izah dan Ibrahim, (2008); Amran dan Devi (2008).

b. Kepemilikan Saham Asing (Foreign Ownership) (X2)

Kepemilikan saham asing dalam penelitian ini menggunakan persentase pemilikan saham pihak/entitas asing (luar negeri). Kepemilikan tersebut minimal sebesar $5 \%$ yang dilihat dalam laporan tahunan perusahaan tahun 2010. Besarnya saham pihak/entitas asing diukur dengan rasio dari jumlah kepemilikan saham asing dibagi total saham perusahaan. Metode pengukuran diatas berdasarkan pengukuran yang telah dilakukan oleh Machmud dan Djakman (2008); Carmelo (2009).

\section{Variabel Kontrol}

a. Ukuran Perusahaan (Firm Size) (X3)

Ukuran perusahaan didefinisikan sebagai besaran atau suatu skala yang menunjukkan suatu usaha. Ukuran perusahaan diukur dari total aset yang dimiliki perusahaan yang diperoleh dari laporan tahunan perusahaan tahun 2010. Ukuran perusahaan yang diukur dengan total aset akan ditransformasikan dalam logaritma untuk menyamakan dengan variabel lain karena total aset perusahaan nilainya relatif besar dibandingkan variabel-variabel lain dalam penelitian ini. Metodepengukuran ini berdasarkan pengukuran yang telah dilakukan oleh Machmud dan Djakman (2008).

$$
\text { SIZE }=\log \text { total aset }
$$

\section{b. Profitabilitas (Profitability) (X4)}

Profitabilitas didefinisikan sebagai kemampuan perusahaan untuk memperoleh laba. Profitabilitas perusahaan diukur dengan Return on Asset (ROA) sebagai mana telah dilakukan dalam penelitian Belkaoui dan Karpik (1987); Carmelo (2009).

\section{Return On Asset $=$ Earning After Tax (EAT)}

\section{Variabel dependen}

Total Asset

Variabel dependen dalam penelitian ini adalah pengungkapan tanggung jawab sosial perusahaan pada laporan tahunan perusahaan dengan menggunakan indikator GRI (Global Reporting Initiative). Alasan digunakannya standar GRI di dalampenelitian ini karena pengungkapan yang terdapat di dalam GRI bersifat internasional dan bisa digunakan untuk berbagai macam sektor dan ukuran perusahaan. Penelusuran item-item pengungkapan tanggung jawab sosial dalam laporan tahunan menggunakan daftar pengungkapan (disclosure list) sebagai panduan, dari setiap item akan diberikan skor untuk menghitung tingkat pengungkapan tanggung jawab sosial perusahaan.

\section{Populasi dan Sampel}

Populasi dalam penelitian ini adalah seluruh perusahaan terbuka yang listing di Bursa Efek Indonesia tahun 2010 yang berjumlah 402 perusahaan Metode pemilihan sampel yang digunakan dalam penelitian ini adalah purposive sampling. Dengan demikian sampel yang digunakan dalam penelitian ini adalah perusahaan terbuka yang terdaftar di Bursa Efek Indonesia tahun 2010 yang memenuhi kriteria pemilihan sampel yang telah ditentukan. Adapun kriteria-kriteria yang digunakan dalam penelitian sampel adalah:

1. Perusahaan tersebut mempublikasikan annual report tahun 2010 paling lambat tanggal 30 April 2011 yang tersedia secara lengkap melalui website BEI (www.idx.co.id ). 
2. Perusahaan tersebut menyediakan informasi mengenai pelaksanaan CSR dan proporsi kepemilikan saham.

3. Perusahaan yang sahamnya dimiliki oleh pihak pemerintah maupun asing.

Berdasarkan kriteria pemilihan sampel tersebut, maka sampel dalam penelitian ini berjumlah 64 perusahaan yang terdaftar di BEI tahun 2010.

\section{Teknik Pengumpulan Data}

Peneliti ini menggunakan metode pengumpulan data sekunder (observasi), yaitu pengumpulan data yang diperoleh dari laporan tahunan perusahaan sampel yang dipublikasikan melalui website Bursa Efek Indonesia (www.idx.co.id) tahun 2010. Data yang digunakan dalam penelitian ini adalah data cross sectional dari 64 perusahaan sampel pada tahun 2010.

\section{Teknik Analisis Data}

Penelitian ini menggunakan metode statistik, untuk menguji apakah kepemilikan saham pemerintah dan kepemilikan saham asing, serta variabel kontrol ukuran perusahaan dan profitabilitas sebagai variabel independen mempunyai pengaruh terhadap pengungkapan tanggung jawab sosial perusahaan sebagai variabel dependen.

Untuk menganalisis data dalam penelitian ini digunakan analisis regresi berganda(multiple regression analysis). Persamaan regresi berganda(multiple regression analysis) yang digunakan dalam penelitian ini adalah sebagai berikut :

$$
Y=\beta_{0}+\beta_{1} X_{1}+\beta_{2} X_{2}+\beta_{3} X_{3}+\beta_{4} X_{4}+\varepsilon
$$

\section{Keterangan :}

$\mathrm{Y}$ adalah Pengungkapan tanggung jawab sosial perusahaan

$\beta_{0}$ adalah konstanta, yaitu nilai $Y$ jika semua variabel $X$ bernilai nol

$\beta_{1}$ adalah koefisien regresi dari $X_{1}$

$\beta_{2}$ adalah koefisien regresi dari $X_{2}$

$\beta_{3}$ adalah koefisien regresi dari $X_{3}$

$\beta_{4}$ adalah koefisien regresi dari $X_{4}$

$\mathrm{X}_{1}$ adalah kepemilikan saham pemerintah (Goverment Ownership)

$\mathrm{X}_{2}$ adalah kepemilikan saham asing (Foreign Ownership)

$\mathrm{X}_{3}$ adalah ukuran perusahaan (Firm Size)

$\mathrm{X}_{4}$ adalah profitabilitas (Profitability)

$\varepsilon$ adalah variabel lain yang tidak diuji

Sebelum dilakukan pengujian hipotesis akan diuji asumsi klasik yang mendasari penggunaan persamaan model regresi berganda sehingga data-data yang akan digunakan dalam pengujian hipotesis bebas dari kemungkinan penyimpangan asumsi klasik, yaitu tidak bias dan memiliki varians yang minimum.

\section{Hasil Penelitian}

\section{Kepemilikan Saham Pemerintah (Government Ownership)}

Kepemilikan saham pemerintah yang dimaksud merupakan porsi kepemilikan saham yang dimiliki pemerintah Republik Indonesia yang masing-masing di atas $5 \%$. Data kepemilikan saham pemerintah bervariasi, hal ini di tunjukkan oleh nilai minimum 0,0000 dan maksimum 0,9002 serta standar deviasi data ini sebesar 0,2952863 atau sekitar 29,53\% dari meansebesar 0,175686 .

\section{Kepemilikan Saham Asing (Foreign Ownership)}

Kepemilikan saham asing yang dimaksud merupakan porsi kepemilikan saham yang dimiliki oleh investor asing atau luar negeri yang masing-masing di atas $5 \%$. Data kepemilikan saham asing juga bervariasi, hal ini di tunjukkan oleh nilai minimum 0,0000 dan maksimum 0,9896 serta standar deviasi data ini sebesar 0,3089012 atau sekitar 30,89\% dari meansebesar 0,360572 . 


\section{Variabel Kontrol Ukuran Perusahaan (Firm Size)}

Data ukuran perusahaan yang diukur berdasarkan nilai total assets perusahaan (log total assets) adalah cukup variatif yang ditunjukkan dengan nilai standar deviasi sebesar 0,9543173 atau $95,43 \%$ dari mean sebesar 12,734239. Ukuran perusahaan berkisar antara 10,5362 (Rp. 34.372.658.505,00) sampai 14,6530 (Rp. 449.774.551.000.000,00). Perusahaan sampel dengan total assets paling tinggi adalah PT. Bank Mandiri (Persero) Tbk yang memiliki total assets sebesar Rp. 449.774.551.000.000,00 sebuah perusahaan yang bergerak di bidang jasa perbankan. Perusahaan dengan nilai total assets yang paling rendah adalah PT. Indoexchange Tbk yang memiliki total assets sebesar Rp. 34.372.658.505,00 sebuah perusahaan yang bergerak di bidang jasa konsultasi manajemen bisnis dan informasi melalui internet.

\section{Variabel Kontrol Profitabilitas Perusahaan (Profitability)}

Profitabilitas perusahaan diukur dengan Return On Assets (ROA) yang dihitung dengan Earning After Tax (EAT) dibagi dengan total assets perusahaan per 31 Desember 2010. DataProfitability perusahaan sampel penelitian ini juga variatif yang ditunjukkan dengan nilai standar deviasi sebesar 0,0568381 atau sekitar 5,68 \% dari mean sebesar 0,066750. Data profitabilityperusahaan sampel penelitian ini berkisar antara 0,0049 sampai dengan 0,2335. Adapun tingkatprofitability tertinggi dimilki oleh PT Semen Gresik (Persero) Tbk dan profitability terendah dimiliki oleh PT. Bank Artha Graha International Tbk.

\section{Model Persamaan Regresi}

Untuk melihat pengaruh kepemilikan saham pemerintah $\left(\mathrm{X}_{1}\right)$ dan kepemilikan saham asing $\left(X_{2}\right)$, serta variabel kontrol ukuran perusahaan $\left(X_{3}\right)$ dan profitabilitas $\left(X_{4}\right)$ terhadap pengungkapan tanggung jawab sosial perusahaan $(Y)$, maka digunakan analisis regresi linier berganda.

Perhitungan koefisien regresi dilakukan dengan menggunakan software SPSS 18.0 untuk analisis regresi berganda disajikan pada tabel 4.7 berikut ini :

Tabel 4.2

\section{Hasil Perhitungan Koefisien Regresi Berganda}

\section{Coefficients $^{\mathrm{a}}$}

\begin{tabular}{|c|c|c|c|c|c|}
\hline \multirow[t]{2}{*}{ Model } & \multicolumn{2}{|c|}{$\begin{array}{l}\text { Unstandardized } \\
\text { Coefficients }\end{array}$} & \multirow{2}{*}{$\begin{array}{c}\text { Standardized } \\
\text { Coefficients } \\
\text { Beta }\end{array}$} & \multirow[b]{2}{*}{$\mathrm{t}$} & \multirow[b]{2}{*}{ Sig. } \\
\hline & B & $\begin{array}{l}\text { Std. } \\
\text { Error }\end{array}$ & & & \\
\hline (Constant) & -.344 & .211 & & -1.629 & .10 \\
\hline (X1) Saham RI & .089 & .064 & .195 & 1.395 & .16 \\
\hline $\begin{array}{l}\text { (X2) Saham } \\
\text { Asing }\end{array}$ & -.031 & .057 & -.072 & -.556 & \\
\hline (X3) Size & .049 & .016 & .347 & 2.968 & .00 \\
\hline $\begin{array}{l}(\mathrm{X} 4) \\
\text { Profitabilitas }\end{array}$ & .640 & .265 & .270 & 2.414 & \\
\hline
\end{tabular}

a. Dependent Variable: (Y) Pengungkapan CSR

Sumber : lampiran hasil output SPSS 18.0

Berdasarkan hasil perhitungan pada tabel 4.7 di atas, diperoleh bentuk persamaan regresi linier berganda sebagai berikut :

$$
Y=-0,344+0,089 X_{1}-0,031 X_{2}+0,049 X_{3}+0,640 X_{4}+\varepsilon
$$

Dari persamaan regresi linier berganda di atas diperoleh nilai konstanta sebesar 0,344 berarti bahwa dengan asumsi variabel bebas kepemilikan saham pemerintah dan kepemilikan saham asing, serta variabel kontrol ukuran perusahaan dan profitabilitas bernilai nol, maka besarnya rata-rata indeks pengungkapan tanggung jawab sosial perusahaan akan bernilai $-0,344$. 
Koefisien regresi untuk variabel $\mathrm{X}_{1}$ positif, menunjukkan adanya hubungan yang searah antara kepemilikan saham pemerintah $\left(X_{1}\right)$ dengan pengungkapan tanggung jawab sosial perusahaan $(Y)$. Koefisien regresi variabel $X_{1}$ sebesar 0,089 mengandung arti setiap perubahan satu satuan total saham yang dimiliki oleh pemerintah dibagi dengan jumlah keseluruhan saham yang beredar sebagai proksi (ukuran) dari kepemilikan saham pemerintah $\left(\mathrm{X}_{1}\right)$ maka akan meningkatkan indeks pengungkapan tanggung jawab sosial perusahaan $(\mathrm{Y})$ sebesar 0,089 pada saat variabel lainnya tidak berubah (ceteris paribus).

Koefisien regresi untuk variabel $\mathrm{X}_{2}$ negatif, menunjukkan adanya hubungan yang berlawanan antara kepemilikan saham asing $\left(\mathrm{X}_{2}\right)$ dengan pengungkapan tanggung jawab sosial perusahaan $(\mathrm{Y})$. Koefisien regresi variabel $\mathrm{X}_{2}$ sebesar mines 0,031 mengandung arti bahwa setiap perubahan satü satuan total saham yang dimiliki oleh pihak asing dibagi dengan jumlah keseluruhan saham yang beredar sebagai proksi (ukuran) dari kepemilikan saham asing $\left(\mathrm{X}_{2}\right)$ maka indeks pengungkapan tanggung jawab sosial perusahaan $(\mathrm{Y})$ akan turun sebesar mines 0,031 pada saat variabel lainnya tidak berubah (ceteris paribus).

Koefisien regresi untuk variabel $\mathrm{X}_{3}$ positif, menunjukkan adanya hubungan yang searah antara ukuran perusahaan $\left(\mathrm{X}_{3}\right)$ dengan pengungkapan tanggung jawab sosial perusahaan $(\mathrm{Y})$. Koefisien regresi variabel $\mathrm{X}_{3}$ sebesar 0,49 mengandung arti setiap perubahan satu satuan total assets sebagai proksi (ukuran) dari ukuran perusahaan $\left(\mathrm{X}_{3}\right)$ maka akan meningkatkan indeks pengungkapan tanggung jawab sosial perusahaan (Y) sebesar 0,049 pada saat variabel lainnya tidak berubah (ceteris paribus).

Koefisien regresi untuk variabel $\mathrm{X}_{4}$ positif, menunjukkan adanya hubungan yang searah antara profitabilitas $\left(\mathrm{X}_{4}\right)$ dengan pengungkapan tanggung jawab sosial perusahaan $(\mathrm{Y})$. Koefisien regresi variabel $\mathrm{X}_{4}$ sebesar 0,640 mengandung arti untuk setiap perubahan satu satuan laba bersih setelah pajak (EAT) dibagi dengan total assets sebagai proksi (ukuran) dariprofitabilitas $\left(\mathrm{X}_{4}\right)$ maka akan meningkatkan indeks pengungkapan tanggung jawab sosial perusahaan (Y) sebesar 0,640 pada saat variabel lainnya tidak berubah (ceteris paribus).

\section{Pengujian Asumsi Klasik Model Regresi}

\section{Uji Normalitas}

Berdasarkan hasil uji Kosmologorov-Smirniov diperoleh nilai statistik ujiKosmologorovSmirniov (D-hitung) sebesar 0,109 dengan signifikansi (p-value) sebesar 0,437. Karena nilai signifikan ( $p$-value) $>0,05$, maka data tersebut berasal dari populasi yang berdistribusi normal. Oleh karena itu, data tersebut memenuhi asumsi normalitas dan dapat digunakan untuk mengambil keputusan.

\section{Uji Multikolinearitas}

Berdasarkan hasil uji multikolinearitas, diketahui bahwa tolerance value keempat variabel bebas lebih besar dari 0,01 dan nilai VIF masing-masing variabel lebih kecil dari 10. Hal ini menunjukkan tidak adanya korelasi yang kuat antara sesama variabel bebas dalam model regresi dan disimpulkan tidak terdapat masalah multikolinearitas di antara sesam variabel bebas dalam model regresi yang dibentuk.

\section{Uji heteroskedastisitas}

Dari grafik scatterplot di atas, dapat diketahui bahwa titik menyebar secara acak serta tersebar baik di atas maupun di bawah angka 0 pada sumbu Y. Dengan demikian dapat disimpulkan bahwa tidah terjadi heteroskedasticitas. Berdasarkan hasil pengujian asumsi klasik di atas, maka dapat dikatakan bahwa model analisis rgresi berganda tersebut sudah memenuhi seluruh asumsi klasik OLS (Ordinary Least Square) karena terbebas dari gejala normalitas, multikolinearitas dan heteroskedastisitas.

\section{Pengujian Hipotesis Statistik}

1. Pengujian Hipotesis Secara Simultan (Uji F-Statistik)

Dari hasil tabel ANOVA dapat dilihat bahwa nilai F-hitung sebesar 6,978 dengan $p$ value sebsar 0,000 . Oleh karena p-value $(0,000)$ lebih kecil dari nilai a yang telah ditetapkan $(0,05)$, maka dapat disimpulkan bahwa variabel bebas (kepemilikan saham pemerintah, kepemilikan saham asing, ukuran perusahaan dan profitabilitas) secara simultan 
berpengaruh signifikan terhadapvariabel tidak bebas (pengungkapan tanggung jawab sosial perusahaan) pada tingkat kepercayaan $95 \%$.

\section{Pengujian Hipotesis Secara Parsial (Uji t-Statistik)}

Untuk mengetahui signifikan atau tidaknya suatu pengaruh dari variabel-variabel bebas secara parsial atas suatu variabel tidak bebas digunakan uji t-statistik. Pengujian hpotesis secara parsial dilakukan dengan cara membandingkan nilai t-hitung dengan nilai t-tabel. Nilai ttabeluntuk tingkat kekeliruan $5 \%$ dan derajat bebas $(\mathrm{db})=\mathrm{n}-\mathrm{k}-1=64-4-1=59$ adalah 1,6711 .

Hasil perhitungan nilai t-hitung untuk masing-masing variabel bebas dalam model regresi yang diteliti dan hasil keputusan uji parsial disajikan pada tabel berikut :

Tabel 4.13 Pengujian Hipotesis Secara Parsial (Uji-t)

\begin{tabular}{|c|c|c|c|c|c|}
\hline Variabel & t-hitung & t-tabel & $\begin{array}{c}\text { P-value } \\
\text { (Sig) }\end{array}$ & $\begin{array}{c}\text { Keputusan } \\
\text { Uji }\end{array}$ & Keterangan \\
\hline $\begin{array}{c}\text { Kepemilikan Saham } \\
\text { pemerintah) }\end{array}$ & 1,395 & 1,6711 & 0,168 & $\mathrm{H}_{0}$ diterima & $\begin{array}{c}\text { Tidak } \\
\text { signifikan } \\
\text { pada } \alpha=0,05\end{array}$ \\
\hline $\begin{array}{c}\mathrm{X}_{2} \\
\text { (Kepemilikan Saham } \\
\text { Asing) }\end{array}$ & $-0,556$ & 1,6711 & 0,581 & $\mathrm{H}_{0}$ diterima & $\begin{array}{c}\text { Tidak } \\
\text { signifikan } \\
\text { pada } \alpha=0,05\end{array}$ \\
\hline $\begin{array}{c}\mathrm{X}_{3} \\
\text { (Ukuran Perusahaan) }\end{array}$ & 2,968 & 1,6711 & 0,004 & $\mathrm{H}_{0}$ ditolak & $\begin{array}{c}\text { Signifikan } \\
\text { pada } \alpha=0,05\end{array}$ \\
\hline $\begin{array}{c}\mathrm{X}_{4} \\
\text { (Profitabilitas) }\end{array}$ & 2,414 & 1,6711 & 0,019 & $\mathrm{H}_{0}$ ditolak & $\begin{array}{c}\text { Signifikan } \\
\text { pada } \alpha=0,05\end{array}$ \\
\hline
\end{tabular}

Keterangan : Jika $\mathrm{t}_{\text {hitung }} \leq \mathrm{t}_{\text {tabel }}: \mathrm{H}_{0}$ diterima atau $\mathrm{H}_{\mathrm{a}}$ ditolak

Jika $\mathrm{t}_{\text {hitung }}>\mathrm{t}_{\text {tabel }}: \mathrm{H}_{\mathrm{a}}$ diterima atau $\mathrm{H}_{0}$ ditolak

Sumber : data diolah

Hasil uji parsial untuk melihat kebermaknaan masing-masing variabel bebas dalam model regresi dapat diuraikan sebagai berikut :

a. Pengaruh kepemilikan saham pemerintah terhadap pengungkapan tanggung jawab sosial perusahaan.

Dari hasil perhitungan, diperoleh nilai hitung untuk variabel kepemilikan saham pemerintah $\left(\mathrm{X}_{1}\right)$ sebesar 1,395 dengan $p$-value sebesar 0,168 . Oleh karena p-value $(0,168)$ lebih besar dari $\alpha$ yang telah ditetapkan $(0,05)$, maka dapat disimpulkan bahwa secara parsial kepemilikan saham pemerintah tidak berpengaruh signifikan terhadap pengungungkapan tanggung jawab sosial perusahaan pada tingkat kepercayaan $95 \%$.

b. Pengaruh kepemilikan saham asing terhadap pengungkapan tanggung jawab sosial perusahaan.

Dari hasil perhitungan, diperoleh nilai hitung untuk variabel kepemilikan saham asing $\left(\mathrm{X}_{2}\right)$ sebesar $-0,556$ dengan $p$-value sebesar 0,581 . Oleh karena $p$-value $(0,581)$ lebih besar dari $\alpha$ yang telah ditetapkan $(0,05)$, maka dapat disimpulkan bahwa secara parsial kepemilikan saham asing tidak berpengaruh signifikan terhadap pengungungkapan tanggung jawab sosial perusahaan pada tingkat kepercayaan $95 \%$.

c. Pengaruh variabel kontrol ukuran perusahaan terhadap pengungkapan tanggung jawab sosial perusahaan

Dari hasil perhitungan, diperoleh nilai hitung untuk variabel kontrol ukuran perusahaan $\left(\mathrm{X}_{3}\right)$ sebesar 2,968 dengan $p$-value sebesar 0,004 . Oleh karena $p$-value $(0,004)$ lebih kecil dari $\alpha$ yang telah ditetapkan $(0,05)$, maka dapat disimpulkan bahwa secara parsial ukuran perusahaan berpengaruh positif dan signifikan terhadap pengungungkapan tanggung jawab sosial perusahaan pada tingkat kepercayaan $95 \%$.

d. Pengaruh variable kontrol profitabilitas terhadap pengungkapan tangung jawab sosial perusahaan

Dari hasil perhitungan, diperoleh nilai hitung untuk variabel kontrol profitabilitas $\left(\mathrm{X}_{4}\right)$ sebesar 2,414 dengan $p$-value sebesar 0,019. Oleh karena $p$-value $(0,019)$ lebih kecil dari $\alpha$ yang telah ditetapkan $(0,05)$, maka dapat disimpulkan bahwa secara parsial profitabilitas berpengaruh 
positif dan signifikan terhadap pengungungkapan tanggung jawab sosial perusahaan pada tingkat kepercayaan $95 \%$.

\section{Koefisien Determinan $\left(\mathbf{R}^{2}\right)$}

Besarnya pengaruh kepemilikan saham pemerintah, kepemelikan saham asing, ukuran perusahaan dan profitabilitas terhadap pengungkapan tanggung jawab sosial perusahaan dalam laporan tahunannya ditunjukkan oleh nilai koefisien determinasi untuk model regresi yang diperoleh. Nilai koefisien determinasi ( $\mathrm{R}$ Square) sebesar 0,321, artinya 32,1\% tingkat pengungkapan tanggung jawab sosial perusahaan dalam laporan tahunannya dapat dipengaruhi oleh kepemilikan saham pemerintah, kepemilikan saham asing, ukuran perusahaan dan profitabilitas. Sedangkan sisanya sebesar $(100 \%-32,1 \%)=67,9 \%$ dapat dipengaruhi oleh variabel-variabel lain yang tidak diteliti dalam penelitian ini.

\section{Pembahasan}

Pengaruh Kepemilikan Saham Pemerintah dan Kepemilikan Saham AsingSecara Simultan terhadap Pengungkapan Tanggung Jawab Sosial Perusahaan yang Terdaftar di Bursa Efek Indonesia.

Berdasarkan hasil analisis data, menunjukkan bahwa secara simultan variable independen yakni kepemilikan saham pemerintah (government ownership) dan kepemilikan saham asing (foreign ownership) berpengaruh signifikan terhadap tingkat pengungkapan tanggung jawab sosial perusahaan, yang ditunjukkan dengan $p$-value 0,000 lebih kecil dari nila $\alpha$ yang telah ditetapkan $(0,05)$. Dengan kata lain model regresi tersebut dapat digunakan untuk menjelaskan hubungan antara variabel $(\mathrm{X})$ dengan variabel $(\mathrm{Y})$ dengan nilai koefisien determinasi $\left(\mathrm{R}^{2}\right)$ sebesar 0,321 .

Hasil penelitian ini mendukung hasil penelitian yang dilakukan oleh penelitianpenelitian sebelumnya seperti penelitian yang dilakukan oleh Machmud dan Djakman (2008); Amran dan Devi (2008); Carmelo (2009) dan Fauzan (2010). Perusahaan yang besar juga mempunyai aktivitas yang lebih banyak, berdampak lebih besar pada lingkungan masyarakat, selain itu juga memiliki kecenderungan public demand yang lebih tinggi akan informasi. Informasi yang dimaksud terutama bagi para pemegang saham, dimana semakin banyak pemegang saham maka laporan yang dibutuhkan juga akan semakin banyak khususnya bagi para pemegang saham yang memiliki perhatian lebih terhadap program-program sosial perusahaan.

Selain itu dengan terjadinya pergeseran paradigma pemikiran terhadap tanggung jawab pengelolaan organisasi, dan dengan semakin kuatnya tuntutan stakeholders dalam hal ini masyarakat, kelompok atau lembaga tertentu atau pemerintah, maka semakin besar pula tekanan yang diterima perusahaan untuk melakukan pengungkapan tanggung jawab sosial perusahaannya. Perusahaan dengan komposisi kepemilikan saham pemerintah dan kepemilikan saham asing tertentu, ukuran besar serta tingkat profitabilitas yang tinggi, tentu saja akan berupaya meningkatkan pengungkapan aktivitas tanggung jawab sosialnya untuk memperbaiki dan meningkatkan image perusahaan, serta sebagai wujud tanggung jawab sosial perusahaan tersebut.

\section{Pengaruh Kepemilikan Saham Pemerintah dan Kepemilikan Saham AsingSecara Parsial terhadap Pengungkapan Tanggung Jawab Sosial Perusahaan yang Terdaftar di Bursa Efek Indonesia. \\ Berdasarkan hasil pengujian koefisien regresi pengaruh kepemilikan saham pemerintah} terhadap pengungkapan tanggung jawab sosial perusahaan, dapat diketahui bahwa kepemilikan saham pemerintah tidak berpengaruh signifikan terhadap pengungkapan CSR dengan nilai thitung $=1,395$ (t-hitung $\leq \mathrm{t}$-tabel) dan $p$-value $=0,168$ (p-value $>0,05)$. Hal ini berarti bahwa semakin tinggi kepemilikan saham pemerintah maka kecenderungan pengungkapan CSR yang terjadi pada perusahaan akan mengalami peningkatan sebesar 0,089 dan tidak signifikan. Hasil pengujian ini sejalan dengan penelitian Fauzan (2010) yang menemukan bahwa kepemilikan saham pemerintah tidak berpengaruh signifikan terhadap tanggung jawab sosial perusahaan. Hal ini menunjukkan bahwa kepemilikan saham pemerintah yang besar belum tentu perusahaan akan melaporkan tanggung jawab sosial yang besar pula. 
Kepemilikan saham pemerintah tidak berpengaruh signifikan terhadap pengungkapan CSR diduga terjadi karena jumlah perusahaan sampel dengan kepemilikan saham pemerintah relatif kecil yakni 18 perusahaan dari 64 perusahaan sampel. Selain itu sampel dengan kepemilikan saham pemerintah dalam penelitian ini heterogen sehingga pengungkapan CSR dalam laporan tahunan perusahaan masih rendah.

Meskipun demikian, dalam tabel 4.7 hasil perhitungan koefisien regresi berganda, nilai B Saham RI bernilai positif yang menunjukkan adanya hubungan yang searah antara kepemilikan saham pemerintah dengan pengungkapan tanggung jawab sosial perusahaan. Selain itu, indeks pengungkapan CSR dengan kepemilikan saham pemerintah menunjukkan indeks tertinggi yaitu sebesar $72,78 \%$ yang dimiliki oleh PT. Aneka Tambang (Persero) Tbk. Beberapa perusahaan dengan kepemilikan saham "pemerintah juga telah mengungkapkan CSR berdasarkan standar GRI (Global Reporting Initiative) seperti PT. Bank BNI (Persero) Tbk, PT. Aneka Tambang (Persero) Tbk, PT. Timah (Persero) Tbk, PT. PP (Persero) Tbk dan PT. Bukit Asam (Persero) Tbk.

Berdasarkan hasil pengujian koefisien regresi pengaruh kepemilikan saham asing terhadap pengungkapan tanggung jawab sosial perusahaan, dapat diketahui bahwa kepemilikan sahamasing tidak berpengaruh signifikan terhadap pengungkapan CSR dengan nilai t-hitung $=0,556$ (t-hitung $\leq \mathrm{t}$-tabel) dan $p$-value $=0,581$ ( $p$-value $>0,05)$. Hal ini berarti bahwa kepemilikan saham asing pada perusahaan di indonesia tidak mempengaruhi luas pengungkapan CSR dalam laporan tahunan perusahaan yang terdaftar di BEI tahun 2010. Dengan kata lain, pihak asing yang memiliki saham di perusahaan Indonesia cenderung tidak menuntut pengungkapan CSR yang luas dalam laporan tahunan, khususnya yang sesuai dengan indikator GRI.

Hasil tersebut sejalan denga penelitian yang dilakukan oleh Amran dan Devi (2008) diMalaysia. Penelitian Machmud dan Djakman (2008) di Indonesia juga menunjukkan hasil yang sama yaitu adanya kepemilikan saham asing pada perusahaan di Indonesia tidak berpengaruh signifikan terhadap pengungkapan CSR.

Dalam Tabel 4.7 hasil perhitungan koefisien regresi berganda, terlihat nilai B saham asing sebesar minus 0,031 artinya jika kepemilikan asing naik 1\%, maka tingkat pengungkapan CSRakan turun sebesar menus 0,031 . Fenomena tersebut menarik karena biasanya masuknya investor asing melalui kepemilikan saham pada perusahaan memiliki kecenderungan meningkatnya pengungkapan tanggung jawab perusahaan terutama kepemilikan Eropa dan United State. Sebagaimana diketahui negara-negara dari kedua benua tersebut memiliki perhatian yang lebih dalam menanggapi masalah-masalah lingkungan dan sosial. Namun dalam penelitian ini menemukan anomali, dimana semakin besar kepemilikan saham asing pada perusahaan di Indonesia maka semakin menurun pengungkapan CSR dalam laporan tahunan perusahaan.

Alasan yang dapat digunakan untuk menjelaskan hal tersebut adalah bahwa didugakepemilikan saham asing pada perusahaan di Indonesia secara umum belum mempedulikan masalah lingkungan dan sosial sebagai isu kritis yang harus diungkapkan dalam laporan tahunanperusahaan. Hal ini diduga terjadi karena sampel perusahaan dengan kepemilikan asing dalampenelitian ini heterogen dan lebih banyak perusahaan selain perusahaan yang terkait langsungdengan sumber daya alam, sehingga pengungkapan CSR dalam laporan tahunan sifatnya masihvoluntary dan sekedar untuk pemenuhan informasi bahwa perusahaan telah melakukan CSR. Aktivitas CSR yang diungkapkan juga lebih kepada indikator ekonomi dan sosial yang bersifatcommunity.

Selanjutnya, hasil penelitian ini tidak berhasil mendukung organizational legitimacy theory yang menyatakan bahwa perusahaan multinasional atau dengan kepemilikan asing utamanya melihat keuntungan legitimasi berasal dari para stakeholrder-nya dimana secara tipikal berdasarkan atas home market (pasar tempat beroperasi) yang dapat memberikan eksistensi yang tinggi dalam jangka panjang (Suchman, 1995 dalam Machmud dan Djakman, 2008).

Hasil penelitian ini membuktikan bahwa kepemilikan saham asing baik perorangan maupun badan usaha pada perusahaan di Indonesia tidak memperhatikan isu-isu lingkungan dan sosial. Adanya berbagai kasus seperti yang terjadi di PT. Freeport Indonesia membuktikan ketidak pedulian investor asing terhadap tanggung jawab sosial perusahaan, sehingga berdampak pada rendahnya tingkat pengungkapan tanggung jawab sosial perusahaan dalam laporan tahunan. 
Jika dilihat dari nilai koefisien regresi kepemilikan saham pemerintah, maka dapat diketahui mana di antara kepemilikan saham pemerintah dan kepemilikan saham asing yang menunjukkan pengaruh yang paling besar terhadap pengungkapan tanggung jawab sosial perusahaan. Berdasarkan tabel 4.5, nilai koefisien regresi kepemilikan saham pemerintah sebesar 0,089 lebih besar dari nilai koefisien regresi kepemilikan saham asing sebesar $-0,031$. Dengan demikian dapat disimpulkan bahwa kepemilikan saham pemerintah pada perusahaan di Indonesia mempunyai pengaruh lebih besar terhadap pengungkapan tanggung jawab sosial perusahaan dibandingkan dengan kepemilikan saham asing. Hal ini disebabkan karena perusahaan dengan kepemilikan saham pemerintah mendapatkan tekanan yang lebih dari pemerintah sebagai pemegang saham pengendali untuk mengungkapkan tanggung jawab sosial perusahaan dalam laporan tahunañnya.

Ukuran perusahaan dalam penelitian ini diproksikan dengan total assets yang dimiliki oleh perusahaan. Hasil pengujian koefisien regresi pengaruh ukuran perusahaan terhadap pengungkapan tanggung jawab sosial perusahaan, menunjukkan bahwa ukuran perusahaanberpengaruh positif signifikan terhadap pengungkapan CSR dengan nilai $t=2,968$ dan $p$-value $=0,004(p$-value $<0,05)$. Hal ini berarti bahwa semakin besar total aktiva yang dimiliki perusahaan, maka semakin tinggi tingkat pengungkapan CSR.

Hasil penelitian ini sejalan dengan penelitian yang dilakukan oleh Chow et al,. (1987); Belkaoui dan Karpik (1989); Hackston dan Milne (1996); Sembiring (2005); Izah dan Ismail (2009); dan Carmelo (2009). Semua hasil penelitian ini, secara umum menyatakan bahwa semakin besar suatu perusahaan maka pengungkapan tanggung jawab sosial perusahaan cenderung semakin luas.

Adanya hubungan yang signifikan antara ukuran perusahaan dan pengungkapan tanggung jawab sosial perusahaan mengandung arti bahwa semakin besar suatu perusahaan, maka akan cenderung melakukan pengungkapan CSR yang lebih luas. Menurut Cowen et. al., (1987), secara teoritis perusahaan besar tidak akan lepas dari tekanan, dan perusahaan yang lebih besar dengan aktivitas operasi dan pengaruh yang lebih besar terhadap masyarakat mungkin akan memiliki pemegang saham yang memperhatikan program sosial yang dibuat perusahaan sehingga pengungkapan tanggung jawab sosial perusahaan akan semakin luas.

Profitabilitas perusahaan dalam penelitian ini diproksikan dengan Return On Assets(ROA) yang dihitung dengan laba bersih setelah pajak (EAT) dibagi dengan total assets(Belkaoui dan Karpik, 1989 dan Carmelo,2009). Hasil pengujian koefisien regresi pengaruhprofitabilitas terhadap pengungkapan tanggung jawab sosial perusahaan, menunjukkan bahwa profitabilitas berpengaruh positif signifikan terhadap pengungkapan CSR dengan nilai $t=2,414$ dan $p$-value $=0,019$ ( $p$-value $<0,05)$. Hal ini berarti bahwa semakin besar profitabilitas yang dimiliki perusahaan, maka semakin luas tingkat pengungkapan CSR.

Penemuan ini menunjukkan bahwa perusahaan yang mempunyai tingkat profitabilitastinggi, maka akan semakin luas tingkat pengungkapan tanggung jawab social perusahaannya. Hal ini mungkin dikarenakan presepsi atau anggapan bahwa aktivitas pengungkapan tanggung jawab sosial perusahaan bukanlah aktivitas yang merugikan bagi keberlangsungan perusahaan. Melainkan aktivitas tanggung jawab sosial perusahaan merupakan langkah strategis yang akan memberikan efek positif bagi perusahaan dalam jangka panjang.

Hasil penelitian ini konsisten dengan hasil yang diperoleh Hossain dkk (2006). Dalam penelitiannya tentang pengungkapan CSR di Bangladesh menemukan bukti bahwa faktor profitabilitas mempunyai hubungan positif terhadap pengungkapan CSR. Hasil penelitian inimendukung pendapat Bowman dan Haire (1976) dan Preston (1978) dalam Hackston dan Milne (1996) yang menyatakan semakin tinggi tingkat profitabilitas perusahaan maka semakin besar pengungkapan informasi sosial.

Alasan yang dapat diajukan atas hasil tersebut adalah bahwa perusahaan di Indonesia akan meningkatkan pengungkapan tanggung jawab sosial ketika memperoleh profit yang tinggi. Artinya bahwa perusahaan di Indonesia sudah mulai menganggap penting keberadaan pengungkapan tanggung jawab sosial. Sehingga semakin besar keuntungan yang diperoleh akan semakin tinggi juga nilai dari kinerja CSR yang dilakukan. 


\section{Simpulan}

1. Kepemilikan saham pemerintah dan kepemilikan saham asing secara simultan berpengaruh signifikan terhadap pengungkapan tanggung jawab sosial perusahaan padaperusahaan yang terdaftar di Bursa Efek Indonesia (BEI)

2. Pengaruh kepemilikan saham pemerintah dan kepemilikan saham asing secara parsialterhadap pengungkapan tanggung jawab sosial perusahaan pada perusahaan yang terdaftar di Bursa Efek Indonesia (BEI), menunjukkan hal-hal sebagai berikut :

a. Kepemilikan saham pemerintah (government ownership) tidak berpengaruh signifikan terhadap pengungkapan tanggung jawab sosial perusahaan yang terdaftar di Bursa Efek Indonesia (BEI).

b. ' Kepemilikan saham asing (foreign ownership) tidak berpengaruh signifikan terhadap pengungkapan tanggung jawab sosial perusahaan yang terdaftar di Bursa Efek Indonesia (BEI).

Saran

1. Hasil penelitian ini menunjukkan bahwa pengungkapan tanggung jawab sosial perusahaan yang disebabkan oleh faktor-faktor lain yang tidak diamati dalam penelitian ini masih relatif besar, sehingga penelitian selanjutnya diharapkan menambah atau menggunakan variablevariabel lain seperti jenis industry, kepemilikan institusi dan lain-lain yang diduga dapat memberikan model pendugaan pengungkapan CSR yang lebih baik.

2. Bagi pemerintah, pelaksanaan Undang-Undang No. 23 tahun 1997 mengenai Pengelolaan Lingkungan Hidup dan Undang-Undang Perseroan Terbatas No. 40 tahun 2007 mengenai kewajiban pelaksanaan tanggung jawab sosial perusahaan belum terlaksana dengan baik, sehingga diharapkan pemerintah lebih tegas dalam memberikan sanksi bagi perusahaan yang melakukan pelanggaran terhadap Undang-Undang tersebut, agar dapat memberikan efek jera kepada perusahaan yang mengabaikan tanggung jawab sosial perusahaannya.

3. Bagi Ikatan Akuntansi Indonesia, sehubungan dengan pengungkapan tanggung jawab sosial perusahaan yang sampai sekarang masih relatif rendah, maka perlu adanya aturan yang jelas mengenai cara pengungkapan tanggungh jawab sosial perusahaan, yaitu standar khususpengungkapan CSR yang disesuaikan dengan kondisi perusahaan di Indonesia, sehingga seluruh perusahaan dapat menggunakan standar yang sama dalam melakukan pengungkapan tanggung jawab sosial perusahaan dalam laporan tahunannya.

4. Bagi pemerintah dan IAI diharapkan mampu merumuskan suatu kebijakan untukmenjadikan pengungkapan tanggung jawab sosial perusahaan sebagai sebuah mandatory disclosure mengingat rendahnya tingkat pengungkapan tanggung jawab sosial yang dilakukan oleh perusahaan.

5. Bagi peneliti berikutnya, sehubungan dengan rendahnya pengungkapan tanggung jawab sosial perusahaan yang disebabkan oleh heterogenitas sampel, maka perlu diteliti lebih lanjut dengan cara menambah jumlah dan homogenitas sampel serta penelitian dilakukan dengan cara studi kasus.

\section{Daftar Pustaka}

Adilla N. Rakhiemah dan Dian Agustia. 2009. Pengaruh Kinerja Lingkungan terhadap Corporate social Responsibility (CSR) Disclosure dan kinerja Finansial Perusahaan pada Perusahaan.yang Terdaftar di Bursa efek Indonesia. Simposium Nasional Akuntansi 12 Palembang.

Amran, Azlan dan S. Susela Devi. 2008. The Impact Of Government And Foreign Affiliate Influence On Corporate Social Reporting (The Case OfMalaysia).Accounting, Auditing and Accountability Journal, Vol. 23, No. 4, hal. 386-404

Anggaini, Fr. RR. 2006. Pengungkapan Informasi Sosial dan Faktor-Faktor yangMempengaruhi Pengungkapan Infromasi Sosial dalam Laporan Keuangan Tahunan (Studi Empiris pada Perusahaan-Perusahaan yang Terdaftar pada Bursa Efek Jakarta). Simposium Nasional Akuntansi 9. 
Belkaoui, A. dan PG. Karpik. 1989. Determinants of the Corporate Decision toDisclose Social Information. Acoounting, Auditing and Accountability Journal, Vol. 2, No. 1, hal. 36-51

Belkaoui, A. 2000. Accounting Theory. Thomson Learning Asia. Edisi Indonesia. Salemba Empat. Jakarta.

Bertens, Kees. 2003. Seri Filsafat: Etika Bisnis. Kanisius. Yogyakarta.

Carmelo, Revento. 2009. Determinants of Corporate Social Responsibility Disclosure Ratings by Spanish Listed Firms. Journal of BussinesEthics.

Caroll, Archie B. 2004. Business and Society, Ethics and Stakeholder anagement. South Western College Publishing. Cincinnati. Ohio, $3^{\text {rd }}$ Edition.

Chow C.W., and Wong-Boren, A. 1987. Voluntary Corporate Disclosure by Mexican Corporations. The Accounting Review Vol. LXII.

Eddy Rismanda Sembiring. 2005. Karakteristik Perusahaan dan PengungkapanTanggung $j$ awab Sosial: Studi Empiris pada Perusahaan yang Tercatat di Bursa Efek Jakarta. Simposium Nasional Akuntansi 8. Solo.

Estes, Rålph. 1976. Corporate Social Accounting. John Wiley and Sons. New York.

Fauzan Ramadhan. 2010. Pengaruh Struktur Kepemilikan dan Karakteristik Perusahaan terhadap Luas Pengungkapan Tanggung Jawab Sosial Perusahaan pada Perusahaan Manufaktur. Tesis tidak dipublikasikan. Universitas Diponegoro.

Freedman. R.E. 1996. Strategic management : A stake holder approach. Boston Fitman. USA.

Gray, R, Owen, D. And Maunders, K. 1995. Corporate social Reporting : Accounting and Accountability. Prentice-Hall, London.

Gujarati, Damodar N. 2010. Basic Ekonometrica. $4^{\text {th }}$ Edition. New York. Mc Graw Hill.

Hackston, D., dan M.J. Milne. 1996. Some determinants of social andenvironmental disclosures in New Zealand companies. Accounting, Auditing and Accountability Journal, Vol. 9, No. 1, hal 77-108.

Haniffa, R.M., dan T.E. Cooke .2005. "The Impact of Culture and Governance onCorporate Social Reporting". Journal of Accounting and Public Policy 24. pp. 391-430.

Hendriksen, Eldon S, dan Van Michael F. Van Breda. 2004. Teori Akunting, Terjemahan oleh Herman Wibowo. Buku dua. Edisi ke-5. Interaksa.

Ikatan Akuntan Indonesia (IAI). 2009. Standar Akuntansi Keuangan. Jakarta. Salemba Empat.

Imam Ghozali dan Anis Chariri. 2007. Teori Akuntansi. Badan Penerbit Undip: Semarang.

I Nyoman Tjager, et al,. 2003. Corporate Governance : Tantangan dan Kesempatan Bagi Komunitas Bisnis Indonesia, Forum for Corporate Governance in Indonesia (FCGI). Prenhallindo. Jakarta.

Ismail, Ku Nor. Izah Ku and Abdul H. Ibrahim. 2008. Social and Environmental Disclosure in the Annual Reports of Jordanis Companies. Issue in Social and Environmental Accounting Vol.2 No. 2.

Jalal. 2011. Perkembangan Mutakhir CSR di Indonesia. Jakarta: Lingkar Studi CSR.

Jensen, Michael C. and William H. Meckling. 1976. Theory of the firm: Managerialbehavior, agency costs, and ownership structure. Journal of Financial Economics 3, 305-360.

Keputusan ketua BAPEPAM No. 134/BL/2006 tentang kewajiban penyampaian laporan tahunan bagi emiten atau perusahaan publik.

Mathews, M.R. 1997. Twenty-five Years of Social of Environmental Accounting Research. Accounting, Auditing, \& Accountability Journal Vol.10 N0.4 p.481-531.

Moir L. 2001, What Do We Mean By Corporate Social Responsibility?; Corporate Governance.

Mudrajad Kuncoro. 2003. Metode Riset untuk Bisnis \& Ekonomi : Bagaimana Meneliti dan Menulis Tesis? Jakarta. Erlangga.

Muslim Utomo. 2000. Praktek Pengungkapan Sosial pada Laporan TahunanPerusahaan di Indonesia (Studi Perbandingan antara Perusahaan HighProfile dan Low Profile. Simposium Nasional Akuntansi 4.

Novita Machmud dan Chaerul D. Djakman. 2008. Pengaruh Struktur Kepemilikan Terhadap Luas Pengungkapan Tanggung Jawab Sosial (CSR Disclosure) Pada Laporan Tahunan Perusahaan: Studi Empiris Pada Perusahaan Publik Yang Tercatat Di Bursa Efek Indonesia Tahun 2006. Simposium Nasional Akuntansi 11.

Nur Indriantoro dan Supomo. 2002. Metodologi Penelitian Bisnis : untuk Akuntansi dan Manajemen. Yogyakarta. BPFE. 
O'Donovan. 2002. Environmental Disclosure in the Annual Report: Extending the Applicability and Predictive Power of Legitimacy Theory. Accounting, Auditing and Accountability Journal. Vol.15, No.3 pp.344-371.

Puspitasari Apriani Daning. 2009. Faktor-Faktor yang mempengaruhiPengungkapan Corporate Social Responsibility (CSR) Pada Laporan Tahunan Perusahaan Di Indonesia. Tesis tidak dipublikasikan. Universitas Diponegoro.

Ramanathan, K.V. 1976. Toward A Theory of Corporate Social Accounting, the Accounting Review. Vol. 51 No. 3, p. 516-528.

Rawi. 2008. Pengaruh Kepemilikan Manajemen, Kepemilikan Institusi dan Leverage terhadap Corporate Social Responsibility pada Perusahaan yang terdaftar di Bursa Efek Indonesia. Tesis. Tidak Dipublikasikan.

Sayekti dan Wondabio. 2007. Pengaruh CSR Disclosure Terhadap EarningsResponse Coefficient. Simposium Nasional Akuntansi 10. Makasar

Sekaran, Uma. 2010. Research Method for bussiness : Askill Building Approach. Jhon Wiley \& Sons Inc, Second edition.

Singgih Santoso. 2003. Buku Latihan SPSS Statistik Parametrik. Alex Media Komputindo, Jakarta. Sofyan Syafri Harahap. 2008. Teori Akuntansi. Edisi Revisi-9. PT. Raja Grafindo Persada. Jakarta.

Sri Sularso. 2004. Metode Penelitian Akuntansi : Sebuah Pendekatan Replikasi. Yogyakarta : BPFE UGM.

Steiner,George Albert and John F. Steiner. 2003. Business, Goverment, and Society: A Managerial Perspective, Text and Cases. McGraw-Hill Higher Education. New York.

Sugiyono. 2010. Metode Penelitian Kuantitatif Kualitatif dan R\&D. Alfabeta. Bandung.

Sujoko Efferin, Stevanus Hadi Darmadi, dan yuliawati Tan. 2008. Metode Penelitian Akuntansi : Mengungkap Fenomena dengan Pendekatan Kualitatif dan Kuantitatif. Yogyakarta. Graha Ilmu.

Shocker, A.D and Sethi,S.P.1974. An Approach to Incorporating SocialPreferences in Developing Corporate Action Strategies. In Sethie,S.P (ed) The Unstable Ground: Corporate Social Policy in a Dynamic Society, Los Angeles: Melville Publishing Company, pp.67-80.

Tanudjaja Bing Bedjo. 2009. Perkembangan Corporate Social Responsibility DiIndonesia. Artikel tidak dipublikasikan. Universitas Kristen Petra Surabaya.

Undang-Undang RI. No. 23 tahun 1997 tentang pengelolaan lingkungan hidup.

Van Horne, J.C and Wachowicz, J.R.2005. Prinsip-prinsip Manajemen Keuangan.Diterjemahkan oleh Dewi Fitriasari, S.S, dan Deni Arnos Kwary, Mhum, Salemba Empat.Jakarta.

Watts, Ross L., and Jerold L. Zimmerman. 1986. Positive Accounting Theory. Prentice-Hall.

Yusuf Wibisono. 2007. Membedah Konsep dan Aplikasi CSR. Fascho Publishing.Gresik. 